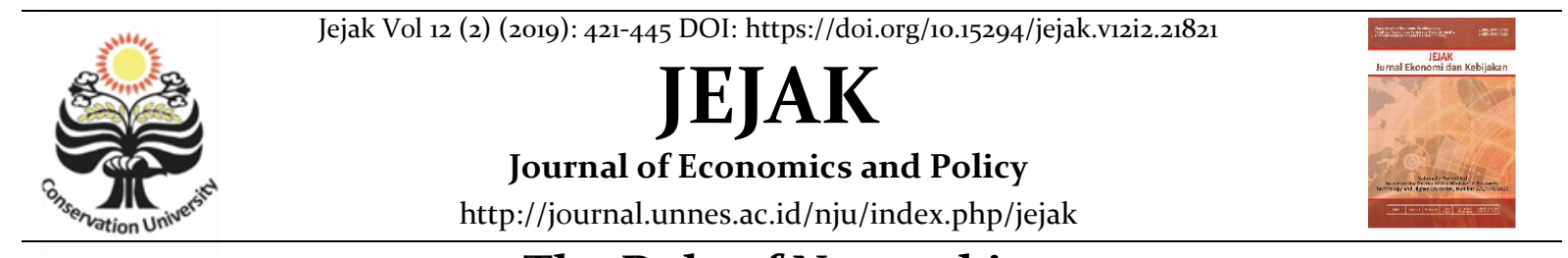

\title{
The Role of Networking in the Internationalization of Indonesian SMEs
}

\author{
Mohamad Dian Revindo', Sri Mulyani Indrawati², Sean Hambali ${ }^{\circledR}{ }^{凶}$
}

${ }^{1}$ Graduate School of Global and Strategic Studies, Universitas Indonesia (SKSG UI)

${ }^{2}$ Department of Economics, Faculty of Economics and Business, Universitas Indonesia (FEB UI)

Institute for Economic and Social Research, Faculty of Economics and Business, Universitas Indonesia (LPEM FEB UI), Jakarta

Permalink/DOI: https://doi.org/10.15294/jejak.v12i2.21821

Received: May 2019; Accepted: July 2019; Published: September 2019

\begin{abstract}
Indonesian SMEs are less able to take advantage of foreign market opportunities than their large counterparts. This study analyses the internationalization of Indonesian SMEs, particularly the differences between exporting and non-exporting SMEs in terms of their network relationships. Primary data was obtained from survey questionnaires in Jawa, Madura and Bali regions, yielding usable responses from 271 exporting SMEs and 226 non-exporting SMEs. Our results suggest that exporters on average have twice as many frequencies of interaction with various external actors than those of their non-exporting counterparts. Exporting and non-exporting SMEs also differ in the way they interact and maintain relationships with external actors. The exporting SMEs utilize various types of interactions including regular and irregular, as well as formal and informal ones, with various external actors in the network. In contrast, non-exporting SMEs are more dependent on personal relations with key persons in various governmental and private institutions. The policy and managerial implications of the findings are discussed.
\end{abstract}

Key words : SMEs, internationalization, network relationships, Indonesia, export assistance

How to Cite: Revindo, M., Indrawati, S., \& Hambali, S. (2019). The Role of Networking in the Internationalization of Indonesian SMEs. JEJAK: Jurnal Ekonomi dan Kebijakan, 12(2). doi:https://doi.org/10.15294/jejak.v12i2.21821

\footnotetext{
Corresponding author : Sean Hambali

Address: Lembaga Penyelidikan Ekonomi dan Sosial,

Fakultas Ekonomi dan Bisnis, Universitas Indonesia (LPEM

FEB UI), Jakarta

E-mail: sean.hambali@gmail.com
}

p-ISSN 1979-715X

e-ISSN 2460-5123 


\section{INTRODUCTION}

Benefits of trade openness are not being distributed equally among countries and enterprises. Despite the growing importance of developing countries in the context of global world trade, the 34 OECD member states - representing developed countries - still accounted for 56-62\% of world merchandise export value during 20102018 (ITC, 2019). At the business level, large enterprises are better positioned to capitalize on trade opportunities as compared to their smaller counterparts. For example, during the mid-2ooos, small and medium-sized enterprises (SMEs) in the US, Switzerland, the Netherlands, United Kingdom, China and Japan only contributed $30-38 \%$ of their respective national exports (Hammer and Stamps, 2010).

SME's inability to exploit any such gains from international trade, particularly amidst the context of rapid growth of global trade, indicates that there exist unequal barriers facing enterprises that are contingent upon the firm's scales. Specifically, SMEs face greater impediments and different challenges to internationalize than their larger counterparts, as they have particular characteristics including the smallness and limited resources that may constrain their international business activities (Kahiya and Dean, 2016, Laghzaoui, 2007, Ruzzier et al., 2006, Paul et al., 2017).

Owing to the complexity of export activities and SMEs' limited internal resources, most SMEs seek external assistance to deal with various export barriers that they are facing. A substantial number of SMEs are involved in extensive networks orchestrated by business associations, cooperatives, leading companies or foreign buyers in certain industries such as fashion accessories (Battaglia et al., 2006, Johnsen, 2007). These networks or supply chains might provide assistance to their members in reaching the global markets (Lim and Kimura, 2010). Furthermore, network relationships can also be built upon private or social-ties, as is the case with both Chinese SMEs (Zhang et al., 2016, Zhou et al., 2007) and British SMEs (Rodrigues and Child, 2012).

SMEs' meagre export contributions are even more prevalent in developing countries. For example, in ASEAN member states on average SMEs only accounted for $23 \%$ of total exports (Wignaraja, 2012). ${ }^{1}$ In Indonesia, SMEs only accounted for a minuscule share of $9.3 \%$ of total non-oil and gas exports despite being a major source of GDP growth and job creation (Wignaraja, 2012). ${ }^{2}$ Despite SMEs' steady rise in total annual export value, their share in Indonesia's non-oil and gas exports shrank continually from around $18.5 \%$ in $2005-07$ to $16.9 \%$ in $2008-10$, around $15.4 \%$ between 2011 and 2013, and further down to less than $15 \%$ in 2016 and 2017 (Ministry of Cooperatives and Small and Medium Enterprises of the Republic of Indonesia, 2018, Ministry of Cooperatives and Small and Medium Enterprises of the Republic of Indonesia, 2009, Ministry of Cooperatives and Small and Medium Enterprises of the Republic of Indonesia, 2015). ${ }^{3}$

\footnotetext{
${ }^{1}$ The Association of Southeast Asian Nations (ASEAN) is a regional economic and political cooperation organisation among Southeast Asian countries. ASEAN was founded in 1967 and currently comprises ten member states namely Indonesia, Malaysia, Philippines, Singapore, Thailand, Brunei Darussalam, Viet Nam, Lao PDR, Myanmar and Cambodia.

${ }^{2}$ Prior to the implementation of the Law No. 20/2008 .on Micro, Small and Medium-Sized Enterprise, the "Small-sized Enterprise" term generally included small and micro-enterprises.

3 If oil and gas exports are included, SMEs' and micro-enterprises' contribution might be even lower since oil and gas exports are performed by large state-owned enterprises. Hence, this figure supports Wignaraja (2012) that Indonesian SMEs' contribution to total exports was actually 9.3\%.
} 
Therefore, Indonesian SMEs are less potent to capitalize on export opportunities from trade liberalization as compared to their larger Indonesian counterparts. The export performances of Indonesian SMEs are also poorer when compared to SMEs from other ASEAN countries and far poorer when compared to SMEs in developed countries. Such poor performances persist despite various policy measures implemented by the Government of Indonesia (GoI), including general assistance (such as access to credit, technical and managerial training) as well as specific export-related assistance (including trade promotion, business matching and training in export procedures). SMEs' inability to capitalize on trade opportunity, coupled with Indonesia's increasing engagement in various free trade agreements (FTAs) - which may force local products to compete directly with cheap imported merchandise in the domestic market - may severely threaten SMEs' business sustainability in the future. ${ }^{4}$

Extant literature suggests that the effectiveness of export-related policies and assistance for SMEs requires a specific but comprehensive understanding of SMEs' export activities. Literature further suggests that a comprehensive analysis of SMEs' exports should include the role of government and network relationships in assisting these businesses to export (Zhang et al., 2016, Kahiya and Dean, 2016, Haddoud et al., 2017, Kontinen and Ojala, 2012, Korhonen et al.,

\footnotetext{
${ }^{4}$ By September 2019, Indonesia had 11 FTAs in effect, including ASEAN (1993), ASEAN-China (2010), ASEAN-Australia and New Zealand (2010), ASEAN-India (2010), ASEAN-Japan (2008), ASEAN-Korea (2007), Indonesia-Japan (2008), Indonesia-Pakistan (2013), Indonesia-Chile (2017), Indonesia-EFTA CEPA (2018) and IndonesiaAustralia (2019). Indonesia also has ongoing negotiations with several other regional and bilateral FTAs.
}

1996, Rodrigues and Child, 2012, Shamsuddoha et al., 2009, Wilkinson and Brouthers, 2006).

Intensive research on firm internationalization only began in the late 1950s, as an attempt to explain multinational enterprises' international activities (Buckley, 2011, Dunning, 2006). During this early period there were several seminal theories of firm internationalization including internalization/ transaction cost, eclectic paradigm, and monopolistic advantage theories (Ruzzier et al., 2006). However, these theories are insufficient to explain international activities of smaller enterprises, namely the SMEs. Such differences lie in the fact that SMEs are much less likely to acquire ownership of their foreign counterparts, as they have no superiority over local firms in corresponding foreign markets. In addition, they also lack the capability to pursue vertical integration to further internalize economic activities abroad which is argued in the eclectic paradigm, monopolistic advantage and internalization theories (Hollenstein, 2005, Onkelinx and Sleuwaegen, 2008).

Such characteristics contribute to a more dynamic and less deterministic internationalization process among the SMEs. The inaptitude of conventional theories in explaining the SMEs internationalization propel the development of second stream of research on firm internationalization which focuses on the international activities of smaller firms. The more contemporary theories developed within this second stream include the stage model, network model, international entrepreneurship approach and resource-based view. Johanson and Vahlne (1977), Johanson and Vahlne (1990) initially developed a firm internationalization model that would later be known as the Uppsala Model. Within the model, it is argued that firms would take rather small incremental, gradual, and sequential steps in intensifying their engagement in international activities. Firms would begin international activities from foreign 
markets which have less psychic distance, or perceived as having much similarities to the home market. Generally, firms usually go through three broad stages/phases in their exporting activities: the pre-engagement/preexport stage; the initial/early export stage; and the advanced export stage - in which firms undergo regular exporting activities, coupled with extensive international experience (Leonidou and Katsikeas, 1996).

In contrast with the Stage Theory that highlights the stages of internationalization, Johanson and Mattsson (1988) instead emphasizes the role of network relationships in firms' internationalization process. A network can be defined as "sets of two or more connected exchange relationships" (Easton and Axelsson, 1992). Networks in the international markets could be perceived as systems of cross-border industrial and social relationships among suppliers, customers, competitors, family, and friends (Coviello and Munro, 1997). Specifically, network relationships are particular mutual contracts in which firms establish and assign positions among themselves, whereas such roles might include suppliers, customers, distributors, the industry, and public and regulatory agencies as well as other market actors.

The availability of such relationships might stimulate and facilitate firms to venture abroad. Additional benefits that can be derived from networking include market knowledge, with which firms can gradually expand their activities beyond current scope and across national borders (Johanson and Mattsson, 1988). For the SMEs, network relationships could serve as a fitting strategy and feasible path towards internationalization, as connections in the network will further minimize their need for knowledge development and for adjustment in international markets. Furthermore, the established connections will also help them exploit prevailing business networks within a foreign market (Abdullah and Zain, 2011, Ruzzier et al., 2006).

However, some researchers have argued that more and more firms - including the small ones - are having their international orientations developed since their establishment. Such phenomenon enables them to become more internationalized in relatively short-time (Chetty and Campbell-Hunt, 2004). As an attempt to better explain this occurrence of rapid firm internationalization, Oviatt and McDougall (1994) proposed the concept of international new ventures (INVs) or the born global firms. The INV refers to a business organization that derives its competitive advantage from its early-established multinational sale of products and resources.

Finally, the Resource-Based View (RBV) conjectures that a firm's competitive advantage mainly originates from its valuable tangible and intangible resources (Wernerfelt, 1984). In the case of internationalization, it is imperative that a firm carefully considers the question of whether its resources can be a source of competitive advantage, that is, if that firm aspires to enter international markets and to export regularly. More specifically, the firm should assess whether its resources are valuable and unique, in the sense that it remains difficult to be imitated or substituted (Barney, 1991). RBV can be applied to further analyze the international activities of smaller firms, because it helps to gauge the firm's likelihood of success as it attempts to expand in foreign markets. Such analysis can be done without having to follow the internationalization phases which are suggested by the stage theory (Peng, 2001, Sari, 2011).

To date, there has not been any single all-encompassing firm internationalization theory that provides an infallible explanation to SME's internationalization, nor is there any such generic theory. This is due to the fact that the process of firms' internationalization and its determinants vary empirically across countries and industries (Onkelinx and Sleuwaegen, 2008, Thai, 2008). In other words, such process and its 
corresponding determinants might potentially be specific to the idiosyncratic nature of each country and industry.

Furthermore, in explaining firms' internationalization process, more recent approaches have been developed, an example of which is the network approach. It is first developed by Johanson and Mattsson (1988) after observing the growing adoption of networking sources by firms to facilitate their internationalization process. Within the context of internationalization, a network can be defined as the firm management team's connection to the firm's customers, suppliers, distributors, competitors, family, friends, bankers, regulatory and public agencies as well as private support agencies, which further enable the firm to expand its business activities beyond domestic markets to overseas counterparts (Coviello and Munro, 1995, Coviello and Munro, 1997, Zain and Ng, 2006). Networking is of paramount importance for SME internationalization, as relationships within the network acts to provide market information, minimize the need for adjustment in a foreign environment, and provide access to established network positions in foreign target markets (Chang and Webster, 2019, Abdullah and Zain, 2011, Ruzzier et al., 2006).

Zain and $\mathrm{Ng}$ (2006) suggest that network relationships provide supportive roles in the SMEs' internationalization process. Such roles include: 1) prompting and driving SMEs' intention to internationalize; 2) influencing SMEs' selection of target market; 3) influencing SMEs' preferred mode of entry; 4) providing access to broader relationships and established channels within foreign markets; 5) providing access to knowledge of designated market; 6) providing initial credibility within new markets; 7) minimizing the costs and risks associated with business activities overseas; 8) exerting influence on pace and patterns of the internationalization.

However, closer tie with a particular international network can also produce adverse effects in that it might possibly constrain the SMEs' future scope and market expansion opportunity. In some cases, complacent firms those that already have close ties with other network members and are more dependent on those members - tend to be less motivated to seek alternative international market opportunities (Zain and $\mathrm{Ng}, 2006$, Coviello and Munro, 1995). As such, the benefits of market access and international reputation remain concentrated to large firms within the network.

From a theoretical point of view, there are at least three reasons of why network relationships play a crucial role in a firm's internationalization process. First, the aforementioned network model suits the SMEs' internationalization analysis because network relationships may potentially help SMEs to overcome various limitations on internal resources that inhibit them to expand beyond domestic markets. Second, as opposed to the stage theory, which conjectures that internationalization only begins from nearby markets (Ojala, 2009, Zain and Ng, 2006), network relationships enable SMEs to begin such process from either close or distant markets. Third, such assistance from network relationships may accelerate the internationalization process of SMEs, contrasting it with the stage theory, which implies the firms' incremental yet gradual progression towards overseas operations (Ojala, 2009).

However, the extant literature differs in classifying the networking sources for entering foreign markets. One commonly used approach is to observe the types of relationships that exist in the international network and subsequently divide such network relationships into formal, informal and intermediary relationships (Ojala, 2009). Formal relationships refer to business 
activities between two or more actors in the international network, while on the other hand, informal relationships refer to personal relationship with relatives, friends and associates. Intermediary relationships can be characterized as having the presence of a third party facilitating the establishment of network relationships between the firm and its foreign buyers or distributors. Other frequently used approach is to look at the networking sources that can be further divided into institutions (including all government agencies), business associates (suppliers, global supply chains, other firms) and personal relations (friends, relatives, colleagues) (Senik et al., 2011).

The existing literature offers a wide variety of views on the manners in which SMEs interact within the networks. Ojala (2009) suggests that SMEs' relationships with actors in the network can develop in either active or passive ways. Active networking is essentially characterized by SMEs' initiatives to build network relationships while passive networking occurs where a network relationship is kick-started by initiatives from the buyers' side. Firms with limited network relationships can assume an active role in building new connections to further facilitate their overseas market expansion. In contrast, network relationships can still occur in spite of passivity on the SMEs' side. Generally, such type of relationships is a by-product of initiatives taken by other actors including customers, importers, distributors or intermediaries. Alternatively, Senik et al. (2011) proposed a network linkage model, in which all networking sources (institutions, business associates and personal relations) work cohesively as a system. The viability of such network linkage system is further safeguarded by the enforcing the facilitation, coordination and monitoring functions of all networking sources. These functions can be performed by a single public body or independent body that connects the potential firms with myriads of public agencies, NGOs, industries, businesses and other actors within the network.

Empirical studies on the role of network relationships in firm internationalization have yielded mixed results. Variations in results are evident across countries, industries, time periods (in which the studies were conducted), forms of internationalization and firm size. The inconclusiveness of network relationships conceptualization, coupled with the problem of fragmented empirical findings further suggest that more research are needed to shed light on this issue.

In the context of Indonesia, to date there has been an extensive body of literature on Indonesian SMEs, but only few sheds light on small firm internationalization. Of those few studies, even less researchess have addressed the internationalization networking issue. For example, Revindo and Gan (2016) investigated how the presence of network sources may stimulate Indonesian SMEs to initiate export activities. It has also been argued that the relationships with external actors determine SMEs' engagement in export market (Revindo and Gan, 2017) and SMEs' export intensity (Revindo and Gan, 2018). However, to the extent of our knowledge there has been no study that specifically investigates types of network sources that the SMEs utilize and the types of interactions engaged by SMEs with external actors in their effort to internationalize. This study aims to fill the gap by investigating how Indonesian SMEs develop network relationships to participate in export markets.

The remainder of the paper is organized as follows. Section 2 presents the method including study area, the data collection procedure and the data analysis method. Section 3 discusses the empirical results. Finally, Section 4 concludes with a summary of the main research findings and the research implications. 


\section{METHOD}

This study narrows its focus on smallsized and medium-sized enterprises hence excludes their micro-sized and large-sized counterparts 5 . Hereafter, SMEs are defined by the number of employees, which ranges from 5 to 99 - in accordance with formal definition from BPS-Statistics Indonesia. It is estimated that $60 \%$ of the currently existing SMEs in the country remains concentrated within 3 islands; namely, Jawa, Madura and Bali (Sabila, 2014).

To construct the sample frame, we merged four different databases into one comprehensive list of SMEs, from which the samples were then picked. The first three databases were published by the Ministry of Cooperatives and SMEs including: (1) the Ministry of Cooperatives and SMEs' online trading board ${ }^{6}$; (2) SME and Cooperative Indonesia Catalogue (Ministry of Cooperatives and SMEs Republic of Indonesia, 2011, 2012)7; and (3) Exporting SMEs Directory Book (Ministry of Cooperatives and SMEs Republic of Indonesia, 2009a) ${ }^{8}$. The fourth database is

5 Micro enterprises are excluded for two reasons. First, the micro enterprises database is unavailable in Indonesia as they are mostly in the form of individual businesses or home industries.

Second, micro enterprises are less likely to engage in international business (Pendergast et al., 2008).

${ }^{6}$ Online promotion at the website of the Ministry of Cooperatives and SMEs:

http://www.indonesian-products.biz.

7 The catalogue provides SMEs' contacts and products description in four languages (English, Arabic, Japanese and Indonesian). The catalogue is published annually as part of the ministry's promotion program.

8 The directory books listed all SMEs that participated in international trade shows organised by the Ministry of Cooperatives and SMEs' during 2005-2009. the Indonesian 2006 Economic Census provided by BPS-Statistics Indonesia. 9 The survey was administered in 2014, during which 971 SMEs were contacted and 497 of which responded (around $51 \%$ response rate).

The sample of 497 SMEs consist of 271 exporting SMEs and 226 non-exporting counterparts. The distribution of the sample by province is as follows: Banten (4.1\%), DKI Jakarta (20.7\%), Jawa Barat (7.0\%), Jawa Tengah (4.8\%), DI Yogyakarta (19.6\%), Jawa Timur (28.0\%) and Bali (15.9\%). The distribution of surveyed SMEs by their main commodities is as follows: agricultural products $(8.5 \%)$, food \& beverages $(6.3 \%)$, furniture $(15.9 \%)$, handicrafts $(21.8 \%)$, garments $(12.2 \%)$, leather products \& fashion accessories (5.5\%), household utensils (5.5\%), machinery components (2.6\%), other products (3.3\%) and multiple products (18.5\%).

In the survey, the SMEs' owners/managers were asked to indicate whether they had received any external assistance to help them overcome various export barriers - including financial, informational, marketing, distribution, human resources, product, procedure and business environment barriers. The respondents were then asked to identify the sources/providers of such assistance, if any, which include: 1) central government agencies; 2) local government agencies; 3) business association/ chambers; 4) private companies/ state owned enterprises (SOEs); 5) universities/research institutes; businesspartners/ associates; 7) Indonesian emigrant communities overseas; and 8) family/relatives (Battaglia et al., 2006, Senik et al., 2011). The respondents were also asked to indicate the helpfulness of assistance received

\footnotetext{
9 The BPS-Statistics Indonesia (National Agency for Statistics) performs economic censuses every ten years. When the survey for this study was conducted in 2014, the most recent census was the 2006 national census.
} 
using a three point Likert-Scale $(1=$ not helpful, 2 = helpful, 3 = very helpful).

The results from the survey are then analyzed as follows. First, we identify the type of networking sources that provide the most assistance (indicated by the provision frequency of such assistances, as reported by the SMEs) and those that provide the most helpful assistance (indicated by highest average scores of helpfulness). Second, we also identify the various types of assistance that are being provided the most by the various networking sources (indicated by count of assistance received by the SMEs) and those that are perceived as being the most useful (scoring highest average scores of helpfulness).

The survey also inquires the forms of relationships that the SMEs established and maintains with the aforementioned eight types of networking sources. Furthermore, such forms of relationships being considered include seven formal relations and two informal relations (Senik et al., 2011). Examples of formal relationships being maintained by the SMEs include: being regular participants in various assistance programs, being irregular participants in all assistance program, making regular contact through formal/official discussions/seminars, making irregular contact through formal/official discussions/ seminars, being a member of a forum set up by agencies /associations/institutes, and involvement in strategic partnership(s). Examples of informal relationships include personal relationships with key persons in the agencies/institutions and making indirect contact with agencies/institutions through another party. The independence test (Chisquare test) is employed to draw the association, between SMEs' export status (exporting and non-exporting SMEs) and the form of relationships that they maintain with various networking sources.

\section{RESULTS AND DISCUSSION}

SMEs gain the information needed to identify export opportunities from various sources. In the survey, respondents who identify themselves as being exporters or aspiringexporters were asked to identify sources of information with which they obtain information regarding export opportunities in foreign target markets. Table 1 shows that both exporters group and their aspiring counterparts use ten sources to obtain such information. However, the Chi-square test performed on comparing both groups indicates that these groups differ in the extent to which they use the individual sources of information.

Business partners/associates and potential buyers are two most utilized sources of information for both SMEs groups. However, the exporters report that business associations and web resources are the third and fourth most important sources of information, while such order are reversed for the aspiring exporters. Further, central government agencies are ranked by the exporters as the fifth most important source of information while for the aspiringexporters it is the media (newspapers, televisions and internet) and family/relatives that rank as the fifth most important source of information. This suggests that government agencies still have further rooms to improve its role in providing informational assistance for SMEs at pre-export stage. Overall, these findings also indicate that exporting SMEs appear to have better network relationships with business associations and central government agencies than its aspiringexporter counterparts. 
Table 1. Sources of Information regarding Export Opportunities

\begin{tabular}{|c|c|c|c|c|c|}
\hline \multirow[t]{2}{*}{ Source of Information } & \multicolumn{2}{|c|}{ Exporter } & \multicolumn{2}{|c|}{$\begin{array}{l}\text { Aspiring } \\
\text { Exporter }\end{array}$} & \multirow{2}{*}{$\begin{array}{l}\text { Statistical } \\
\text { Test }\end{array}$} \\
\hline & Count & $\%$ & Count & $\%$ & \\
\hline Newspapers and television & 31 & $4.9 \%$ & 23 & $8.3 \%$ & \multirow{10}{*}{$\begin{array}{l}\chi^{2}= \\
42.049^{* * *}\end{array}$} \\
\hline Web/internet resources & 68 & $10.8 \%$ & 51 & $18.3 \%$ & \\
\hline Business association & 72 & $11.4 \%$ & 25 & $9.0 \%$ & \\
\hline Business partners/associates & 152 & $24.1 \%$ & 68 & $24.5 \%$ & \\
\hline Central government agencies & 59 & $9 \cdot 4 \%$ & 13 & $4 \cdot 7 \%$ & \\
\hline Regional government agencies & 36 & $5 \cdot 7 \%$ & 12 & $4 \cdot 3 \%$ & \\
\hline Family/relatives & 39 & $6.2 \%$ & 23 & $8.3 \%$ & \\
\hline $\begin{array}{l}\text { Indonesian emigrant societies in target } \\
\text { markets }\end{array}$ & 7 & $1.1 \%$ & 8 & $2.9 \%$ & \\
\hline Contact made by buyer & 148 & $23.5 \%$ & 54 & $19 \cdot 4 \%$ & \\
\hline Trade Show/Expo & 19 & $3.0 \%$ & 1 & $0.4 \%$ & \\
\hline Total & & $100 \%$ & & $100 \%$ & \\
\hline
\end{tabular}

The counts exceed the number of respondents because each respondent may identify more than one source of information

Source: Author's calculation based on survey data

Table 2 shows the types of relationships maintained by SMEs with various sources of networking. It shows that different networking sources correspondingly entail different types of relationships. The type of relationships being maintained between SMEs and central government agencies mainly occurs in the form of participation in programs designed specifically to support SMEs. Around $28.6 \%$ of respondents interacting with central government agencies stated that they have been regular participants of such programs. Other notable forms of interactions include having personal relations with key persons within the government agency (16.4\%) and being irregular participants of the same programs (16\%).

The same phenomenon can be observed in the context of Regional Government Agencies, whereas most of the interactions made between the SMEs and these government agencies also occur in the form of participation in various SMEs supporting programs. However, the data also shows that percentage of regular participation in the regional government's programs is significantly lower (by almost 7 percentage points) than its central counterparts. Such observation suggests further room for the Regional Government to increase its engagement in the process of supporting the SMEs.

SMEs are most engaged with business association/chambers in the form of being members of forums set up by these institutions. For this type of interaction, business associations have proven to be prominent when compared to other networking sources (highest percentage of $19.7 \%$ ). Other notable forms of interactions also include having personal relations with key persons within the association (16\%) and being regular participants in various SMEs supporting programs (13.7\%).

Interactions being made between the SMEs and universities/research institutes mainly occur in the form of being irregular participants in all supporting programs for SMEs (21.5\%), indicating the presence of spillover effect from technological developments being made within the academic 
institutions. However, such interactions are not regularly attended - suggesting further role for improving this type of interaction in order to magnify the spillover effect. Other noteworthy types of relationships also include having indirect contact through other party $(21.5 \%)$ and having personal relation with key persons.

In relation to private companies/ SOEs, the types of relationships being maintained with the SMEs are mostly in forms of having personal relation with key persons (18.8\%). Other noteworthy types of interactions include being both regular and irregular participants in all SMEs supporting programs ( $16.8 \%$ and $14.7 \%$, respectively), and the development of strategic partnerships (11.7\%). Moreover, results from horizontal comparison - indicating the relative importance of a networking source for a given type of relationship - demonstrate the fact that these companies still serve minor roles in providing network assistance for the SMEs, as their percentages are significantly lower than that of other networking sources. 
Table 2. Types of Relationships Maintained by SMEs with Various Sources of Networking

\begin{tabular}{|c|c|c|c|c|c|c|c|c|c|c|c|c|c|c|c|c|c|c|c|c|c|c|c|c|c|c|c|}
\hline & \multirow{2}{*}{$\begin{array}{l}\text { Types of Relations } \\
\text { Maintained }\end{array}$} & \multicolumn{3}{|c|}{$\begin{array}{c}\text { Central Government } \\
\text { Agencies }\end{array}$} & \multicolumn{3}{|c|}{$\begin{array}{c}\text { Regional } \\
\text { Government } \\
\text { Agencies } \\
\end{array}$} & \multicolumn{3}{|c|}{$\begin{array}{c}\text { Business Association/ } \\
\text { Chambers }\end{array}$} & \multicolumn{3}{|c|}{$\begin{array}{c}\text { University/ } \\
\text { Research Institutes }\end{array}$} & \multicolumn{3}{|c|}{$\begin{array}{c}\text { Private Companies } \\
\text { /SOEs }\end{array}$} & \multicolumn{3}{|c|}{$\begin{array}{c}\text { Business Partners/ } \\
\text { Associates }\end{array}$} & \multicolumn{3}{|c|}{ Family/ Relatives } & \multicolumn{3}{|c|}{\begin{tabular}{|c|}
$\begin{array}{c}\text { Indonesian Emigrant } \\
\text { Communities }\end{array}$ \\
\end{tabular}} & \multicolumn{2}{|c|}{$\begin{array}{c}\text { Total by Types } \\
\text { of Relations }\end{array}$} \\
\hline & & $\mathrm{n}$ & $\begin{array}{c}\% \text { of } \\
\text { column }\end{array}$ & $\begin{array}{l}\% \text { of } \\
\text { row }\end{array}$ & $\mathrm{n}$ & \%o of colum & $\begin{array}{l}\% \text { of } \\
\text { row }\end{array}$ & $\mathrm{N}$ & po of colum & \% of & $\mathrm{N}$ & $\begin{array}{c}\% \text { of } \\
\text { column }\end{array}$ & $\begin{array}{l}\% \text { of } \\
\text { row }\end{array}$ & $\mathrm{n}$ & $\begin{array}{c}\% \text { of } \\
\text { column }\end{array}$ & $\begin{array}{l}\% \text { of } \\
\text { row }\end{array}$ & $\mathrm{n}$ & oo of colum & $\begin{array}{l}\% \text { of } \\
\text { row }\end{array}$ & $\mathrm{n}$ & oo of colum & $\begin{array}{l}\% \text { of } \\
\text { row }\end{array}$ & $\mathrm{n}$ & $\begin{array}{c}\% \text { of } \\
\text { column }\end{array}$ & ro of row & $\mathbf{n}$ & row of \\
\hline A & \begin{tabular}{|c}
$\begin{array}{l}\text { Regular participant in all } \\
\text { supporting programs for } \\
\text { SMEs }\end{array}$ \\
\end{tabular} & 68 & 28.6 & 29.6 & 65 & 21.7 & 28.3 & 55 & 13.7 & 23.9 & 9 & 11.4 & 3.9 & 33 & 16.8 & 14.3 & o & 0.0 & 0.0 & 0 & 0.0 & 0.0 & 0 & 0.0 & 0.0 & 230 & 100.0 \\
\hline B & $\begin{array}{c}\begin{array}{c}\text { Irregular participant in } \\
\text { all supporting programs } \\
\text { for SMEs }\end{array} \\
\end{array}$ & 38 & 16.0 & 20.7 & 56 & 18.7 & 30.4 & 44 & 11.0 & 23.9 & 17 & 21.5 & 9.2 & 29 & 14.7 & 15.8 & o & 0.0 & 0.0 & o & 0.0 & 0.0 & o & 0.0 & 0.0 & 184 & 100.0 \\
\hline C & \begin{tabular}{|c|}
$\begin{array}{c}\text { Regular contact through } \\
\text { formal/ official } \\
\text { discussions/ seminars }\end{array}$ \\
\end{tabular} & 19 & 8.0 & 21.8 & 27 & 9.0 & 31.0 & 25 & 6.2 & 28.7 & 8 & 10.1 & 9.2 & 8 & 4.1 & 9.2 & o & 0.0 & 0.0 & o & 0.0 & 0.0 & o & 0.0 & 0.0 & 87 & 100.0 \\
\hline D & \begin{tabular}{|c|} 
Irregular contact \\
through formal/ official \\
discussions/ seminars
\end{tabular} & 16 & 6.7 & 17.8 & 30 & 10.0 & 33.3 & 28 & 7.0 & 31.1 & 7 & 8.9 & 7.8 & 9 & 4.6 & 10.0 & o & 0.0 & 0.0 & o & 0.0 & 0.0 & $\mathrm{o}$ & 0.0 & 0.0 & 90 & 100.0 \\
\hline E & $\begin{array}{c}\text { Member of forum set up } \\
\text { by agencies/ } \\
\text { associations/ institutes }\end{array}$ & 26 & 10.9 & 16.0 & 37 & 12.3 & 22.8 & 79 & $19 \cdot 7$ & 48.8 & 4 & 5.1 & 2.5 & 16 & 8.1 & 9.9 & o & 0.0 & 0.0 & o & 0.0 & 0.0 & o & 0.0 & 0.0 & 162 & 100.0 \\
\hline $\mathrm{F}$ & Strategic partnership(s) & 10 & 4.2 & 3.8 & 10 & $3 \cdot 3$ & 3.8 & 31 & $7 \cdot 7$ & 11.7 & 3 & 3.8 & 1.1 & 23 & 11.7 & 8.6 & 122 & 28.5 & 45.9 & 63 & 36.8 & 23.7 & 4 & 16.7 & 1.5 & 266 & 100.0 \\
\hline $\mathrm{H}$ & $\begin{array}{l}\text { Personal relation with } \\
\text { key persons }\end{array}$ & 39 & 16.4 & 11.7 & 46 & $15 \cdot 3$ & 13.8 & 64 & 16.0 & 19.2 & 11 & 13.9 & $3 \cdot 3$ & 37 & 18.8 & 11.1 & 100 & 23.4 & 30.0 & 30 & 17.5 & 9.0 & 6 & 25.0 & 1.8 & 333 & 100.0 \\
\hline I & $\begin{array}{l}\text { Indirect contact through } \\
\text { other party }\end{array}$ & 14 & 5.9 & 5.1 & 19 & 6.3 & 6.9 & 42 & 10.5 & 15.2 & 17 & 21.5 & 6.2 & 24 & 12.2 & 8.7 & 108 & 25.2 & 39.1 & 41 & 24.0 & 14.9 & 11 & 45.8 & 4.0 & 276 & 100.0 \\
\hline \multicolumn{2}{|r|}{$\begin{array}{l}\text { Total by the Sources of } \\
\text { Networking }\end{array}$} & 238 & 100.0 & & 300 & 100.0 & & 401 & 100.0 & & 79 & 100.0 & & 197 & 100.0 & & 428 & 100.0 & & 171 & 100.0 & & 24 & 100.0 & & & \\
\hline
\end{tabular}

Source: Author's calculation based on survey data 
Types of relationships between the SMEs and Business Partners/Associates are mostly manifested in the form of strategic partnerships (28.5\%). Other types of relationships that are worth noting include informal relationship - in the form of indirect contact through other party $(25.2 \%)$ and personal relation with key persons (22.9\%), and joint projects between the two business entities $(\mathbf{2 2 . 9} \%)$. It is interesting to note that the business partners/associates have proven to exert significant role in providing network assistance to the SMES. For example, they are most prominent in establishing strategic partnerships and joint projects with the SMEs (45.9\% and $46.7 \%$ compared to other networking sources). This might be attributed to their smaller scale as compared to the private companies/SOEs, which provides them with a competitive edge in coordinating with the grassroots companies.

The same phenomenon can be observed for the family/relatives source of networking. A horizontal comparison also demonstrates the fact that the SMEs also counted on their families/relatives to provide them strategic partnerships $(23.7 \%$ compared to other networking sources). In addition, this networking source is also counted on by the SMEs to establish joint projects (17.6\%). Meanwhile, the data also shows that emigrant communities have played an astonishingly minor role despite the importance of their role in bridging the gap between international and domestic markets.

Table 3 displays the differences between exporting and non-exporting SMEs in terms of frequencies of contact/interaction made with these eight types of networking sources. There are observed similarities and differences among exporting SMEs and their nonexporting counterparts, particularly in terms of types of networking sources being accessed. Both of these groups have the most frequent network access to business partners/associates and business associations/chambers and the least frequent interaction with Indonesian overseas diaspora communities.

One of the stark differences between the exporting and non-exporting SME groups lies in the number of interactions being reported, as the former reports 1,144 interactions as compared to 694 by the latter. Table 3 below also infers that exporting SMEs exhibit a more balanced interaction between central and local government agencies $(15.30 \%$ and $15.12 \%$, respectively), whereas non-exporting SMEs tend to interact more closely with local government agencies as compared to the central counterparts $(18.30 \%$ and $9.08 \%$, respectively). This may potentially be driven by the fact that local government agencies tend to possess stronger local market orientation in extending their assistance, while the central government agencies may have a more global vision in identifying market opportunities for SMEs (Uchikawa and Keola, 2008). 
Table 3. Differences in SMEs' Interaction with Various Networking Sources

\begin{tabular}{lccccc}
\hline \multirow{2}{*}{ Networking Sources } & \multicolumn{2}{c}{ Exporter } & Aspiring Exporter & Statistical \\
& Count & $\%$ & Count & $\%$ & Test \\
\hline Central Government Agencies & 175 & $15.30 \%$ & 63 & $9.08 \%$ & \\
Regional Government Agencies & 173 & $15.12 \%$ & 127 & $18.30 \%$ & \\
Business Association/Chambers & 254 & $22.20 \%$ & 147 & $21.18 \%$ & \\
Universities/Research Institutes & 41 & $3.58 \%$ & 38 & $5.48 \%$ & \\
Private Companies /SOEs & 115 & $10.05 \%$ & 82 & $11.82 \%$ & $\chi^{2}=$ \\
Business Partners/Associates & 270 & $23.60 \%$ & 158 & $22.77 \%$ & $22.888^{* * *}$ \\
Family/Relatives & 99 & $8.65 \%$ & 72 & $10.37 \%$ & \\
Indonesian Emigrant Communities & 17 & $1.49 \%$ & 7 & $1.01 \%$ & \\
Central Government Agencies & 175 & $15.30 \%$ & 63 & $9.08 \%$ & \\
Regional Government Agencies & 173 & $15.12 \%$ & 127 & $18.30 \%$ & \\
\hline Total & 1144 & $100 \%$ & 694 & $100 \%$ & \\
\hline Note: $\quad{ }^{* * *}$ represents a 1\% significance level & & & &
\end{tabular}

The counts exceed the number of respondents because each respondent may identify more than one source of information Source: Author's calculation based on survey data

Table 4. Differences in Types of Relationships Maintained with the Networks

\begin{tabular}{|c|c|c|c|c|c|}
\hline \multirow{2}{*}{ Networking Sources } & \multicolumn{2}{|c|}{ Exporter } & \multicolumn{2}{|c|}{$\begin{array}{l}\text { Aspiring } \\
\text { Exporter }\end{array}$} & \multirow{2}{*}{$\begin{array}{l}\text { Statistical } \\
\text { Test }\end{array}$} \\
\hline & Count & $\%$ & $\begin{array}{l}\text { Cou } \\
\text { nt }\end{array}$ & $\%$ & \\
\hline $\begin{array}{l}\text { Regular participant in all supporting programs for } \\
\text { SMEs }\end{array}$ & 147 & $12.85 \%$ & 83 & $11.96 \%$ & \\
\hline $\begin{array}{l}\text { Irregular participant in all supporting programs for } \\
\text { SMEs }\end{array}$ & 121 & $10.58 \%$ & 63 & $9.08 \%$ & \\
\hline $\begin{array}{l}\text { Regular contact through formal/official } \\
\text { discussions/seminars }\end{array}$ & 57 & $4.98 \%$ & 30 & $4.32 \%$ & \\
\hline $\begin{array}{l}\text { Irregular contact through formal/official } \\
\text { discussions/seminars }\end{array}$ & 68 & $5.94 \%$ & 22 & $3.17 \%$ & \\
\hline $\begin{array}{l}\text { Member of forum set up by } \\
\text { agencies/associations/institutes }\end{array}$ & 111 & $9.70 \%$ & 51 & $7 \cdot 35 \%$ & $45 \cdot 278^{* * *}$ \\
\hline Strategic partnership(s) & 177 & $15.47 \%$ & 89 & $12.82 \%$ & \\
\hline Joint project(s) & 142 & $12.41 \%$ & 68 & $9.80 \%$ & \\
\hline Personal relation with key persons & 190 & $16.61 \%$ & 143 & $20.61 \%$ & \\
\hline Indirect contact through other party & 131 & $11.45 \%$ & 145 & $20.89 \%$ & \\
\hline $\begin{array}{l}\text { Regular participant in all supporting programs for } \\
\text { SMEs }\end{array}$ & 147 & $12.85 \%$ & 83 & $11.96 \%$ & \\
\hline Total & 1144 & $100 \%$ & 694 & $100 \%$ & \\
\hline
\end{tabular}


We then investigate the differences between exporting and non-exporting SMEs in terms of channels with which these SMEs build and maintain interactions with various networking actors/sources. Table 4 displays the nine types of formal and informal interactions made between the SMEs and their networking sources, ranging from intense and regular interaction (Regular participant in all supporting programs for SMEs) to informal and irregular interaction (Indirect contact through other party).

Table 4 shows that exporting and nonexporting SMEs differ in the channels they utilize to maintain relationship with external actors, as reflected by the significant chisquare statistics (at $1 \%$ significance level). Exporting SMEs make use of both regular and irregular as well as both formal and informal interactions to maintain existing networks. On the other hand, non-exporting SMEs tend to rely more on personal relations with key persons in governmental/private institutions. In addition, strong tendency to rely on indirect contact through other party is also observed among the non-exporting SMEs. These differences serve as one of the key factors that distinguish the exporting SMEs and their non-exporting counterparts.

We further explore the means with which the exporting SMEs use networking sources to assist them in their export activities. Table 5 summarizes the number of export-related assistance that these SMEs received from their networks for each export task/function. The last two columns in Table 5 show the ranks and the average helpfulness score of each type of assistance received. The latter is measured on a three-point Likert Scale $(1=$ not helpful, $2=$ helpful, $3=$ very helpful).

From Table 5, one can derive the conclusion that most of the assistance given to the exporting SMEs comes in the form of informational assistance regarding foreign market export opportunities, which amounts to 636 counts (21\% of total assistance counts). Other noteworthy assistance provided by external actors in the network include marketing and promotional activities (299 counts), working capital (273) and improvement in managerial team capabilities (259). On the other hand, export-related activities that have been receiving the least attention include unequal treatment in foreign markets (69 counts of assistance), export guarantees and insurance (71), contracts and dispute settlement with foreign customers (90) and anticipation of foreign market turbulent economic conditions (93).

However, the counts of assistance do not necessarily provide information on the helpfulness of the assistance being provided. The last column in Table 5 shows that assistance on the capital needs of these SMEs are perceived to be the most useful assistance, scoring an average of 2.48. Other assistances strongly perceived to be useful also include information related to export opportunities (with an average score of 2.47) and promotional activities (2.46). On the other hand, assistances that are least perceived to be useful are generally informational assistance with regards to business environment functions, such as unequal treatment in foreign countries (2.27), followed by informational assistance on differences in business practices at the destination market (2.28) and differences pertaining to regulation in foreign countries (2.29). 
Table 5. Assistance Received by SMEs from the Networks for Various Export Functions

\begin{tabular}{|c|c|c|c|c|}
\hline \multirow{2}{*}{ Export Tasks/Functions } & \multicolumn{2}{|c|}{$\begin{array}{l}\text { Assistance } \\
\text { Counts }\end{array}$} & \multicolumn{2}{|c|}{$\begin{array}{c}\text { Assistance } \\
\text { Helpfulness }\end{array}$} \\
\hline & Rank & Count & Rank & Score \\
\hline FINANCE: Working capital or investment funds for internationalization or credit facilities for foreign customers & (3) & 273 & (1) & 2.48 \\
\hline $\begin{array}{l}\text { INFORMATION: Obtaining information on foreign markets' data and analysis, business opportunities and potential } \\
\text { customers }\end{array}$ & (1) & 636 & (2) & 2.47 \\
\hline MARKETING: Designing promotional activities and competition strategy in target markets & $(2)$ & 299 & (3) & 2.46 \\
\hline $\begin{array}{l}\text { DISTRIBUTION: Obtaining reliable foreign representations/contacts (who are communicative, reputable and have solid } \\
\text { operating networks) }\end{array}$ & (7) & 163 & (4) & 2.42 \\
\hline $\begin{array}{l}\text { BUSINESS ENVIRONMENT: Enforcing contracts/resolving disputes in foreign markets and collecting payment from foreign } \\
\text { customers }\end{array}$ & (14) & 90 & (5) & 2.41 \\
\hline $\begin{array}{l}\text { BUSINESS ENVIRONMENT: Anticipating target markets' change in economic conditions, exchange rate risks and political } \\
\text { instability }\end{array}$ & (13) & 93 & (6) & 2.40 \\
\hline HUMAN RESOURCES: Increase the capacity/capability of managerial team \& personnel for internationalization & (4) & 259 & (7) & 2.39 \\
\hline PRODUCT: Developing new products \& adapting product design/style for foreign market & (5) & 208 & (8) & 2.39 \\
\hline PROCEDURE: Understanding export procedures/paperwork, both in Indonesia or across borders & (6) & 198 & (9) & 2.39 \\
\hline $\begin{array}{l}\text { PRODUCT: Meeting foreign markets' product quality/standards/specifications or health, safety and technical standards in } \\
\text { foreign markets }\end{array}$ & (9) & 136 & (10) & 2.38 \\
\hline PROCEDURE: Export guarantee or insurance for both products and assets abroad & $(15)$ & 71 & $(11)$ & 2.38 \\
\hline $\begin{array}{l}\text { DISTRIBUTION: Supplying inventory and spare-parts abroad on time, providing warehouse/inventory facilities and offering } \\
\text { technical/after-sales service abroad }\end{array}$ & (11) & 122 & (12) & 2.38 \\
\hline MARKETING: Countering negative image of Indonesian products & (8) & 153 & (13) & 2.34 \\
\hline $\begin{array}{l}\text { BUSINESS ENVIRONMENT: Understanding regulation in foreign countries with regard to tariff classification, quota and } \\
\text { intellectual property rights }\end{array}$ & (12) & 110 & (14) & 2.29 \\
\hline $\begin{array}{l}\text { BUSINESS ENVIRONMENTS: Understanding foreign business practices, socio-cultural trait differences and different } \\
\text { verbal/nonverbal language, communicating with overseas customers \& understanding their habits/attitudes }\end{array}$ & (10) & 124 & (15) & 2.28 \\
\hline $\begin{array}{l}\text { BUSINESS ENVIRONMENT: Ensuring fair \& equal treatment with other firms in target markets in terms of taxation, } \\
\text { eligibility to affiliate, asset ownership, and movement of people }\end{array}$ & $(16)$ & 69 & (16) & 2.27 \\
\hline
\end{tabular}

Note: The counts exceed the number of respondents because each respondent may receive assistance in more than one export function. Source: Author's calculation based on survey data 
We then identify the types of networking sources that most actively provide export-related assistance and the most useful assistance, as perceived by the exporting SMEs. The findings are summarized in Table 6 below.

From the table, we observe that business partners and associates provide the most export-related assistance for the SMEs, amounting to 1,016 counts of assistance for all 16 export functions. Other noteworthy networking sources that provide the most assistance for SMEs include central government agencies (499) and business associations/chambers (410).

In contrast, we also note that universities/research institutes and Indonesian emigrant communities abroad provide the least export-assistance (59 and 98 respectively). This is indicative of the rather weak partnerships between research institutes/universities and SMEs, particularly if one considers the crucial role that these research bodies can play in creating innovations and developing cutting-edge products. Likewise, the relatively lack of support from diaspora communities is also worth mentioning, since their role in further connecting domestic SMEs to foreign markets are also of paramount importance.

The last column in Table 6 shows that the assistance provided by private companies/state-owned enterprises and assistance from family/relatives are perceived by SMEs to be the most helpful. On the other hand, it is worth noting that the assistance provided by central and local government agencies neither ranks on top of the assistance provision counts nor on top of the helpfulness score. There are at least two ways in which government agencies can improve their currently existing provision of export assistance. First, the government may consider increasing assistance provision related to the export functions that still have low assistance counts. In other words, the government may choose to focus on providing assistance in export functions that have not been adequately assisted by other networking sources. In this case, the government may concentrate their efforts in giving informational assistance related to the business environment or barriers in export procedures.

Alternatively, the government can also choose to focus on assisting export functions that still rank low in terms of average helpfulness score. In other words, the government may focus on providing assistance in export functions for which the current types of assistance from various networking sources are still ineffective. In this case, the government may concentrate their effort in addressing the business environment issues.

However, it can also be argued that the government does not always have to intervene in the network relationships activities (Yamin and Ghauri, 2004). In our study context, the government may refrain from being directly involved in every export function (i.e. providing assistance for each export function). Instead, the government may coordinate, facilitate or strengthen the relationship between SMEs and their business partners/associates, private companies/SOEs and business associates/ chambers (Senik et al., 2011). Such example would be facilitating the meetings, partnerships or cooperation between SMEs and their various networking sources. Hence, rather than intervening heavily by designing export assistance programs, the government may instead enhance existing networks in order to ensure that they function efficiently in providing assistance to the exporting SMEs. 
Table 6. Main Providers of Export Assistance for SMEs

\begin{tabular}{|c|c|c|c|c|}
\hline \multirow[t]{2}{*}{ Networking Sources } & \multicolumn{2}{|c|}{ Assistance Counts } & \multicolumn{2}{|c|}{$\begin{array}{c}\text { Assistance's } \\
\text { Helpfulness Score }\end{array}$} \\
\hline & Rank & Count & Rank & Count \\
\hline Private Companies/SOE Services & (6) & 190 & (1) & 2.433 \\
\hline Family/ Relatives & (4) & 367 & (2) & 2.423 \\
\hline Local Government Agencies & (5) & 365 & (3) & 2.416 \\
\hline Business Partners/Associates & $(1)$ & 1,016 & (4) & 2.408 \\
\hline Indonesian Emigrant Communities & (7) & 98 & (5) & 2.405 \\
\hline Universities/ Research Institutes & (8) & 59 & (6) & 2.404 \\
\hline Central Government Agencies & (2) & 499 & (7) & 2.402 \\
\hline Business Association/Chambers & (3) & 410 & (8) & 2.401 \\
\hline Private Companies/SOE Services & (6) & 190 & (1) & 2.433 \\
\hline
\end{tabular}

Note: The counts exceed the number of respondents because each respondent may identify more than one source of information Source: Author's calculation based on survey data 
Table 7. Export Assistance for Various Export Tasks/Functions and Their Perceived Helpfulness

\begin{tabular}{|c|c|c|c|c|c|c|c|c|c|c|c|c|c|c|c|c|c|c|c|c|}
\hline & \multirow{3}{*}{ Export Tasks/ Functions } & \multicolumn{18}{|c|}{ Frequency of assistance received by SMEs from: } & \multirow{3}{*}{$\begin{array}{l}\text { Assistance's } \\
\text { Helpfulness } \\
\text { Score }\end{array}$} \\
\hline & & \multicolumn{2}{|c|}{$\begin{array}{l}\text { Central } \\
\text { Government } \\
\text { Agencies }\end{array}$} & \multicolumn{2}{|c|}{$\begin{array}{l}\text { Regional } \\
\text { Government } \\
\text { Agencies }\end{array}$} & \multicolumn{2}{|c|}{$\begin{array}{l}\text { Family/ } \\
\text { Relatives }\end{array}$} & \multicolumn{2}{|c|}{$\begin{array}{l}\text { Business } \\
\text { Partners/ } \\
\text { Associates }\end{array}$} & \multicolumn{2}{|c|}{$\begin{array}{l}\text { Business } \\
\text { Association/ } \\
\text { Chambers }\end{array}$} & \multicolumn{2}{|c|}{$\begin{array}{l}\text { Private } \\
\text { Companies/ } \\
\text { SOE }\end{array}$} & \multicolumn{2}{|c|}{$\begin{array}{l}\text { Universities/ } \\
\text { Research } \\
\text { Institutes }\end{array}$} & \multicolumn{2}{|c|}{$\begin{array}{c}\text { Indonesian } \\
\text { Emigrant } \\
\text { Communities }\end{array}$} & \multicolumn{2}{|c|}{ Total Assistance } & \\
\hline & & $\mathrm{n}$ & $\%$ of row & $\mathrm{N}$ & $\%$ of row & $\mathrm{n}$ & $\%$ of row & $\mathrm{N}$ & $\%$ of row & $\mathrm{N}$ & $\%$ of row & $\mathrm{n}$ & $\%$ of row & $\mathrm{n}$ & $\%$ of row & $\mathrm{n}$ & $\%$ of row & $\mathrm{n}$ & $\%$ of row & \\
\hline A & $\begin{array}{l}\text { INFORMATION: Business opportunities } \\
\text { abroad }\end{array}$ & 87 & 13.7 & 101 & $15 \cdot 9$ & 95 & 14.9 & 221 & $34 \cdot 7$ & 75 & 11.8 & 22 & 3.5 & 9 & 1.4 & 26 & 4.1 & 636 & 100 & 2.47 \\
\hline $\mathrm{B}$ & $\begin{array}{l}\text { HUMAN RESOURCES: Capability of } \\
\text { managerial team \& personnel }\end{array}$ & 39 & 15.1 & 47 & 18.1 & 32 & 12.4 & 81 & 31.3 & 39 & 15.1 & 8 & 3.1 & 10 & 3.9 & 3 & 1.2 & 259 & 100 & 2.39 \\
\hline C & $\begin{array}{l}\text { FINANCE: Working capital or investment } \\
\text { funds }\end{array}$ & 22 & 8.1 & 32 & 11.7 & 72 & 26.4 & 45 & 16.5 & 19 & 7 & 76 & 27.8 & 3 & 1.1 & 4 & 1.5 & 273 & 100 & 2.48 \\
\hline $\mathrm{D}$ & PRODUCT: Developing the products & 15 & 7.2 & 20 & 9.6 & 28 & 13.5 & 101 & 48.6 & 27 & 13 & 5 & 2.4 & 4 & 1.9 & 8 & 3.8 & 208 & 100 & 2.39 \\
\hline $\mathrm{E}$ & PRODUCT: Quality \& standards & 26 & 19.1 & 13 & 9.6 & 6 & 4.4 & 63 & 46.3 & 19 & 14 & 2 & 1.5 & 3 & 2.2 & 4 & 2.9 & 136 & 100 & 2.38 \\
\hline $\mathrm{F}$ & PROCEDURE: Export procedures \& paperwork & 53 & 26.8 & 44 & 22.2 & 11 & 5.6 & 53 & 26.8 & 23 & 11.6 & 7 & 3.5 & 5 & 2.5 & 2 & 1 & 198 & 100 & 2.39 \\
\hline G & PROCEDURE: Export guarantee or insurance & 16 & 22.5 & 6 & 8.5 & 7 & 9.9 & 23 & 32.4 & 9 & 12.7 & 8 & 11.3 & 1 & 1.4 & 1 & 1.4 & 71 & 100 & 2.38 \\
\hline $\mathrm{H}$ & $\begin{array}{l}\text { DISTRIBUTION: Reliable foreign } \\
\text { representations/contacts }\end{array}$ & 19 & 11.7 & 10 & 6.1 & 14 & 8.6 & 78 & 47.9 & 25 & $15 \cdot 3$ & 4 & 2.5 & 2 & 1.2 & ${ }^{11}$ & 6.7 & 163 & 100 & 2.42 \\
\hline I & $\begin{array}{l}\text { DISTRIBUTION: Inventory, spare-part \& after- } \\
\text { sales service abroad }\end{array}$ & 11 & 9 & 8 & 6.6 & 13 & 10.7 & 52 & 42.6 & 18 & 14.8 & 16 & 13.1 & 2 & 1.6 & 2 & 1.6 & 122 & 100 & 2.38 \\
\hline $\mathrm{J}$ & $\begin{array}{l}\text { MARKETING: Promotional activities \& } \\
\text { competition strategy in target markets }\end{array}$ & 71 & 23.7 & 32 & 10.7 & 27 & 9 & 91 & 30.4 & 44 & 14.7 & 16 & 5.4 & 10 & 3.3 & 8 & 2.7 & 299 & 100 & 2.46 \\
\hline K & $\begin{array}{l}\text { MARKETING: Countering negative image of } \\
\text { Indonesian products }\end{array}$ & 50 & 32.7 & 14 & 9.2 & 9 & 5.9 & 35 & 22.9 & 26 & 17 & 8 & 5.2 & 2 & 1.3 & 9 & 5.9 & 153 & 100 & 2.34 \\
\hline $\mathrm{L}$ & $\begin{array}{l}\text { BUSINESS ENVIRONMENTS: Understanding } \\
\text { foreign business practice }\end{array}$ & 15 & 12.1 & 9 & $7 \cdot 3$ & 17 & 13.7 & 47 & 37.9 & 23 & 18.5 & 5 & 4 & 2 & 1.6 & 6 & 4.8 & 124 & 100 & 2.28 \\
\hline $\mathrm{M}$ & $\begin{array}{l}\text { BUSINESS ENVIRONMENT: Ensuring fair \& } \\
\text { equal treatment in target markets }\end{array}$ & 11 & 15.9 & 9 & 13 & 8 & 11.6 & 19 & 27.5 & 14 & 20.3 & 3 & 4.3 & 3 & 4.3 & 2 & 2.9 & 69 & 100 & 2.27 \\
\hline $\mathrm{M}$ & $\begin{array}{l}\text { BUSINESS ENVIRONMENT: Understanding } \\
\text { regulation in foreign countries }\end{array}$ & 30 & 27.3 & 12 & 10.9 & 10 & 9.1 & 32 & 29.1 & 17 & 15.5 & 2 & 1.8 & 2 & 1.8 & 5 & 4.5 & 110 & 100 & 2.29 \\
\hline $\mathrm{O}$ & $\begin{array}{l}\text { BUSINESS ENVIRONMENT: Target markets } \\
\text { economic \& political instability }\end{array}$ & 19 & 20.4 & 4 & 4.3 & 7 & 7.5 & 32 & 34.4 & 18 & 19.4 & 7 & 7.5 & 1 & 1.1 & 5 & 5.4 & 93 & 100 & 2.4 \\
\hline $\mathrm{P}$ & $\begin{array}{l}\text { BUSINESS ENVIRONMENT: Contract } \\
\text { enforcement \& payment collection }\end{array}$ & 15 & 16.7 & 4 & 4.4 & 11 & 12.2 & 43 & 47.8 & 14 & 15.6 & 1 & 1.1 & o & o & 2 & 2.2 & 90 & 100 & 2.41 \\
\hline \multicolumn{2}{|c|}{ Network Sources Counts } & 499 & & 365 & & 367 & & 1016 & & 410 & & 190 & & 59 & & 98 & & & & \\
\hline \multicolumn{2}{|c|}{ Helpfulness of the Network Source } & \multicolumn{2}{|c|}{2.402} & \multicolumn{2}{|c|}{2.416} & \multicolumn{2}{|c|}{2.423} & \multicolumn{2}{|c|}{2.408} & \multicolumn{2}{|r|}{2.401} & \multicolumn{2}{|r|}{2.433} & \multicolumn{2}{|r|}{2.404} & \multicolumn{2}{|r|}{2.405} & & & \\
\hline
\end{tabular}

Source: Author's calculation based on survey data 
Table 7 details the number of export assistance that SMEs received from the networks for various export tasks/functions. With regards to export assistances received from central government agencies, the SMEs stated that these government agencies mostly provide them with information on business opportunities abroad (87 of all assistance provided by the agencies). In addition, there are several other forms of export assistance that have been provided more by the government and less by other networking sources. Such assistances include those related to export procedures and marketing functions. The former aims to provide the SMEs with relevant information regarding export procedures and other paperwork needed in the export process. On the other hand, the latter is more concerned with countering negative images of Indonesian products.

Similar to their central government counterparts, the regional government agencies also mostly provide the SMEs with information related to business opportunities abroad (101 of all assistance provided). Such assistance is also higher in frequency compared to those provided by their central government counterparts, which might be possibly due to the regional government's closer proximity to the SMEs. Moreover, the table also clearly shows that regional government agencies specialize in providing human resources-related assistances (18.1\% of all human-resources related assistance).

Being the highest assistance-providing network source, most of the assistances provided by business partners/associates are also related to information on opportunities abroad. However, it is noteworthy that this institution provides the highest number of opportunity-related information as compared to other networking sources. Other assistance mostly provided by the association/chambers are related to product development (101 of all assistance provided) and marketing functions (91 of all assistance provided). In contrast, universities/research institutes provide the least number of assistance to SMEs. If any, such assistances occur in forms of human-resource related or marketing-related assistances.

Private companies/SOEs also play a crucial role in the process of assisting the SMEs, as they mostly channel assistances perceived to be most helpful by the SMEs. Such assistances are related to meeting the financial needs of the SMEs. Of all finance-related assistances, around $\mathbf{2 7 . 8} \%$ are provided by private companies/SOEs. The prowess of these companies in providing SMEs with capital access are arguably due to their large business scale, and therefore capital base, which further enables them to engage in venture capital practices. Other noteworthy assistances provided by these companies also include information-related ( 22 of all assistance provided), distribution-related (16), and marketing-related assistances (16).

As with the government entities and business partner, business associates/chambers mostly assists the SMEs by providing information on opportunities abroad (75 of all assistances provided). Other assistances being provided by the associates/chambers include marketing-related (44) and human-resource related assistances (39). Those closest to the SMEs managerial boards, that is, their family/relatives, are counted on to provide finance-related export assistance. Such phenomenon can be attributed to strong sentiment of kinship prevalent within Indonesian grassroots business communities, which further enables the SMEs to receive loans at lower or zero interest rates.

Despite the importance of bridging domestic players with international markets, Indonesian emigrant communities are among the lowest assistance-providing network 
sources. Its total assistance to SMEs only amounts to 98 , as compared to 1,016 assistances provided by business partners/associates. Most assistances provided by these diaspora communities come in form of information related to business opportunities abroad (26 of 98 assistances being provided). However, the number of such assistances can be further magnified to better target foreign markets and thereby increasing the profitability of exporting activities.

The above-elaborated results suggest that exporting SMEs, as with the case for aspiring-exporters, should also seek to maintain and strengthen their relationships with various non-government actors within the network. These exporting SMEs may seek advice or information related to export expansion opportunities from business associations/chambers and business partners/associates. In addition, the current exporters should also build networking with Indonesian emigrant (diaspora) communities to provide them further access to multiple foreign markets. The role of the Indonesian diaspora is still very limited and ineffective in facilitating SME internationalization when compared to other communities, such as guanxi (China), kankei (Japan) and immak (Korea) (Zhou et al., 2007, Zhang et al., 2016).

The results further provide several academic implications. Our findings are consistent with the Network Model of internationalization. In line with Johanson and Mattsson (1988), we found that network relationships are of crucial importance for SME internationalization, as indicated by the fact that exporting SMEs did indeed build more intensive interactions and close relationships with various government agencies and non-government actors than did the non-exporting SMEs. Through these external actors, SMEs attain reliable information on export opportunities and foreign market. Such external actors include business associates/partners, foreign buyers and business associations/ chambers. Accordingly, we also observed that SMEs require financial, managerial, technical and promotional assistance from both central government agencies and non-government sources to become exporters, and to further sustain and expand their export activities.

\section{CONCLUSION}

Network relationships play a crucial role in facilitating the internationalization of Indonesian SMEs. Our results suggest that exporters have twice as many frequencies of interaction with external actors than those of their non-exporting counterparts. Such external actors include central and local government agencies, business associations/chambers, universities/research institutes, private companies/SOEs, business partners/associates, family/ relatives and Indonesian emigrant communities overseas. Exporters and non-exporters also differ in the types of network sources that they mainly utilize. The exporting SMEs show close interactions with both central and local government agencies, whereas non-exporting SMEs are more inclined to establish close interactions with local government agencies than to central government institutions.

Further, exporting and non-exporting SMEs also differ in the way they interact and maintain relationships with external actors. The exporting SMEs utilize various types of interactions including regular and irregular, as well as formal and informal ones, with various external actors in the network. In contrast, nonexporting SMEs are more dependent on personal relations with key persons in various governmental and private institutions.

External actors in these SMEs' networks provide export assistance that is mostly related with the supply of information regarding foreign market business opportunities, marketing 
and promotional activities. Moreover, we find that assistance associated with unequal treatment in foreign markets, export guarantees and insurance, and contracts and dispute settlement (with foreign customers) remains small in amount. However, we find that the type of assistance perceived as the most helpful by these enterprises is assistance in terms of working capital. Conversely, these enterprises perceive assistance associated with business environment functions (including unequal treatment in foreign countries) as being the least helpful assistance.

Our results also suggest that the networking sources which provide the most export assistance to SMEs are business partners/associates, central government agencies and business associations/ chambers. On the other hand, the sources that are perceived to provide the least export assistance are universities/research institutes and Indonesian diaspora communities overseas. It is worth mentioning that the frequency of assistance being provided does not necessarily reflect the helpfulness of such assistance. As such, our study suggests that SMEs perceive assistance provided by private companies, state-owned enterprises and family/relatives as being the most beneficial for them.

Government agencies also play a paramount role in facilitating the internationalization of SMEs. We observed that exporting SMEs receive more assistance from the central government as compared to their non-exporting counterparts in all types of assistance, including international trade fairs, publication of SME Catalogues, managerial training, technical training, and export financing, insurance and guarantees.

The findings of the study have several important policy implications. The government should be more informed of the functions and role of non-government actors within the internationalization network. Such non-government actors include business associations/chambers, research institute/ universities, finance/microfinance institutions and other non-government organizations. Moreover, government intervention should incorporate the network relationships between SMEs and other actors that are already at work.

Thus, the government should define the appropriate level of intervention for each policy area. Direct intervention (export assistance provision) might be suitable for export tasks that have not yet been adequately provided by nongovernment actors within the network. An example might be the intensification of efforts by the government to address issues of business environment barriers in foreign markets, such as SMEs' insufficient knowledge of target markets' regulations, procedures and business practices, and the negative image of Indonesia or Indonesian products. Such types of barriers are beyond non-government actors' capability to deal with, and should be within the government's scope of action.

On the other hand, in the case where nongovernment actors have provided adequate assistance to these exporting enterprises, indirect intervention may then be preferred over direct intervention. As such, it is not imperative, for example, that the government establishes a new form of financial institution or any new schemes to support SMEs export. Rather, the government may instead opt to strengthen the operation of currently existing non-government actors, such as the Indonesia Eximbank, to increase its service outreach and to raise SMEs' awareness of the bank's services.

Example of other alternatives include the assignment of one public body by the government to facilitate, connect, coordinate and monitor the myriads of private and public agencies that possess the same area of interest or assistance (Senik et al., 2011). For example, the government may assign the Directorate General 
for National Export Development, Ministry of Trade, to pool all relevant information concerning export opportunity from various institutions/ sources. The coordinated work of various agencies might potentially increase the effectiveness of the export assistance being provided.

The findings of the study also have several managerial implications. Nonexporting SMEs aspiring to export should proactively seek export assistance from central government agencies. Aspiring-exporters should also knit and maintain close relationships with various non-government actors within the network. Some network actors that might potentially assist SMEs in the internationalization process include, but are not limited to, business associations/chambers, business partners/ associates, private companies/state-owned enterprises, universities/research institutes, suppliers, distributors and Indonesian emigrant communities worldwide. Our findings suggest that network relationships with non-government actors within the network can be as important as the formal relationships with government agencies in facilitating SMEs to export.

The study has some limitations, upon which future research in this topic can be developed. First, this study used the SMEs' points of view in elaborating the role of network sources and network relationships in SMEs internationalization. Future studies can rather elicit perspectives from various actors in the internationalization networks, including distributors, suppliers, business associations/ chambers, financial institutions and other private agencies to have a better understanding on how the networks assist SMEs to internationalize.

Second, this study is based on the survey data collected in 2014, since which SMEs' export participation may have changed. However, this study may represent the SME internationalization in Indonesia before the beginning of the first term of current ruling government (2014-2019). Another similiar survey, therefore, is encouraged, with which the current government's effort to foster SMEs internationalization during 2014-2019 can be evaluated.

\section{REFERENCES}

Abdullah, N. A. H. N. \& Zain, S. N. M. 2011. The internationalization theory and Malaysian small medium enterprises (SMEs). International Journal of Trade, Economics and Finance, 2, 318-322.

Barney, J. 1991. Firm resources and sustained competitive advantage. Journal of management, 17, 99-120.

Battaglia, L., Corsaro, D. \& Tzannis, A. 2006. The role of networks in the internationalisation of a SME: the case of an Italian company. Industrial Marketing and Purchasing Group Conference. Milano.

Buckley, P. J. 2011. The theory of international business pre-Hymer. Journal of World Business, 46, 61-73.

Chang, F. Y. \& Webster, C. M. 2019. Influence of innovativeness, environmental competitiveness and government, industry and professional networks on SME export likelihood. Journal of Small Business Management, 57, 1304-1327.

Chetty, S. \& Campbell-Hunt, C. 2004. A strategic approach to internationalization: A traditional versus a "born-global" approach. Journal of International Marketing, 12, 57-81.

Coviello, N. E. \& Munro, H. J. 1995. Growing the entrepreneurial firm: networking for international market development. European Journal of Marketing, 29, 4961. 
Coviello, N. E. \& Munro, H. J. 1997. Network relationships and the internationalisation process of small software firms. International Business Review, 6, 361-386.

Dunning, J. 2006. American investment in British manufacturing industry, Routledge.

Easton, G. \& Axelsson, B. 1992. Industrial networks: a new view of reality, Routledge.

Haddoud, M. Y., Jones, P. \& Newbery, R. 2017. Export promotion programmes and SMEs' performance: Exploring the network promotion role. Journal of Small Business Enterprise Developmen, 24, 68-87.

Hammer, A. \& Stamps, J. 2010. The Role of Small \& Medium Sized Enterprises In U.S. and EU Exports. Paris: OECD.

Hollenstein, H. 2005. Determinants of international activities: are SMEs different? Small Business Economics, 24, 431-450.

ITC. 2019. Trade Map: Export by Products. The International Trade Centre.

Johanson, J. \& Mattsson, L.-G. 1988. Internationalization in Industrial Systems - A Network Approach. In: HOOD, N. \& VAHLNE, J.-E. (eds.) Strategies in Global Competition. New York: Routledge.

Johanson, J. \& Vahlne, J.-E. 1977. The internationalization process of the firm--A model of knowledge development and increasing foreign market commitments. Journal of International Business Studies (pre1986), 8, 23-32.

Johanson, J. \& Vahlne, J.-E. 1990. The mechanism of internationalisation. International Marketing Review, 7, 1124.
Johnsen, R. E. 2007. The role of focal suppliers in strategic networks for internationalisation: Perspectives from small and medium-sized Italian and Thai silk suppliers. Journal of Fashion Marketing and Management, 11, 135-147.

Kahiya, E. T. \& Dean, D. L. 2016. Export stages and export barriers: Revisiting traditional export development. Thunderbird International Business Review, 58, 75-89.

The Ministry of Cooperatives and Small and Medium Enterprises of the Republic of Indonesia. 2009. The KUKM Export Directory. Jakarta.

The Ministry of Cooperatives and Small and Medium Enterprises of the Republic of Indonesia. 2015. Data Development of Micro, Small, Medium Enterprises (UMKM) and Large Enterprises (UB) in 2012-2013. [On line]. [Accessed September 10 2016].

The Ministry of Cooperatives and Small and Medium Enterprises of the Republic of Indonesia. 2018. Development of Data on Micro, Small, Medium Enterprises (UMKM) and Large Enterprises (UB) in 2016-2017. [On line]. [Accessed December 10 2019].

Kontinen, T. \& Ojala, A. 2012. Social capital in the international operations of family SMEs. Journal of Small Business and Enterprise Development, 19, 39-55.

Korhonen, H., Luostarinen, R. \& Welch, L. 1996. Internationalization of SMEs: Inward-outward patterns and government policy. Management International Review, 36, 315-329.

Laghzaoui, S. 2007. Internationalization of SME: A reading in terms of resources and competencies. 3rd Iberian International Business Conference. Aveiro, Portugal. 
Leonidou, L. C. \& Katsikeas, C. S. 1996. The export development process: an integrative review of empirical models. Journal of international business studies, 27, 517-551.

Lim, H. \& Kimura, F. 2010. The Internationalization of Small and Medium Enterprises in Regional and Global Value Chains. ADBI Working Paper No. 231.

OJALA, A. 2009. Internationalization of knowledge-intensive SMEs: The role of network relationships in the entry to a psychically distant market. International Business Review, 18, 5059 .

Onkelinx, J. \& Sleuwaegen, L. 2008. Internationalisation of SMEs. Flanders District of Creativity.

Oviatt, B. M. \& Mcdougall, P. P. 1994. Toward a theory of international new ventures. Journal of international business studies, 25, 45-64.

Paul, J., Parthasarathy, S. \& Gupta, P. 2017. Exporting challenges of SMEs: A review and future research agenda. Journal of World Business, 52, 327342.

Pendergast, W. R., Sunje, A. \& Pasic, M. 2008. The internationalization of SMEs in Bosnia and Herzegovina. In: Dana, L.-P., Wellpe, I. M., Han, M. \& Ratten, V. (eds.) Handbook of Research on European Entrepreneurship: Towards a Theory of Internationalization London: Edward Elgar.

Peng, M. W. 2001. The resource-based view and international business. Journal of Management, 27, 803-829.

Revindo, M. D. \& Gan, C. 2016. Export Stimuli, Export Stages and Internationalization Pathways: The Case of Indonesian SMEs. EFI, 62, 191205 .
Revindo, M. D. \& Gan, C. 2017. Factors Influencing SMEs Engagement in Direct Export Activities. LPEM, Faculty of Economics and Business, University of Indonesia.

Revindo, M. D. \& Gan, C. 2018. Factors Affecting Variation in SMES'Export Intensity. LPEM, Faculty of Economics and Business, University of Indonesia.

Rodrigues, S. B. \& Child, J. 2012. Building social capital for internationalization. Revista de Administração Contemporânea, 16, 23-38.

Ruzzier, M., Hisrich, R. D. \& Antoncic, B. 2006. SME internationalization research: past, present, and future. Journal of Small Business and Enterprise Development, 13, 476-497.

Sabila, F. 2014. Perancangan Promosi Produk UKM Plasa Pameran Kementerian Perindustrian. Universitas Multimedia Nusantara.

Sari, D. Internationalisation of Manufacturing SMEs: The Case of Indonesia. International Council for Small Business (ICSB) World Conference 2011 Washington. International Council for Small business (ICSB), 1.

Senik, Z. C., Scott-Ladd, B., Entrekin, L. \& Adham, K. A. 2011. Networking and internationalization of SMEs in emerging economies. Journal of International Entrepreneurship, 9, 259281.

Shamsuddoha, A. K., Ali, M. Y. \& Ndubisi, N. O. 2009. Impact of government export assistance on internationalization of SMEs from developing nations. Journal of Enterprise Information Management, 22, 408-422.

Thai, M. T. T. 2008. The internationalization of Vietnamese small and medium-sized enterprises. Doctora Oeconomiae, University of St. Gallen. 
Uchikawa, S. \& Keola, S. 2008. Small and medium enterprises in Cambodia, Laos, and Vietnam. ERIA Research Project Report 2008, 237-273.

Wernerfelt, B. 1984. A resource-based view of the firm. Strategic Management Journal, 5, 171-180.

Wignaraja, G. 2012. Engaging Small and Medium Enterprises in Production Networks: Firm-level Analysis of Five ASEAN Economies. ADBI Working Paper Series No. 361. ADBI.

Wilkinson, T. \& Brouthers, L. E. 2006. Trade promotion and SME export performance. International Business Review, 15, 233-252.

Yamin, M. \& Ghauri, P. N. 2004. Rethinking MNE-emerging market relationships: Some insights from East Asia. In: PRASAD, S. B. \& GHAURI, P. N. (eds.) Global Firms and Emerging Markets in an Age of Anxiety. London: Praeger.

Zain, M. \& Ng, S. I. 2006. The impacts of network relationships on SMEs' internationalization process. Thunderbird International Business Review, 48, 183-205.

Zhang, X., Ma, X., Wang, Y., Li, X. \& Huo, D. 2016. What drives the internationalization of Chinese SMEs? The joint effects of international entrepreneurship characteristics, network ties, and firm ownership. International Business Review, 25, 522-534.

Zhou, L., Wu, W.-P. \& Luo, X. 2007. Internationalization and the performance of born-global SMEs: the mediating role of social networks. Journal of International Business Studies, 38, 673-69o. 